\title{
Gambaran jenis kanker ovarium di RSUP Prof. Dr. R.D. Kandou Manado periode Januari 2013 - Desember 2015
}

\author{
${ }^{1}$ Imanuel T. Gea \\ ${ }^{2}$ Maria F. Loho \\ ${ }^{3}$ Freddy W. Wagey
}

\author{
${ }^{1}$ Kandidat Skripsi Fakultas Kedokteran Universitas Sam Ratulangi Manado \\ ${ }^{2}$ Bagian Obstetri dan Ginekologi Fakultas Kedokteran Universitas Sam Ratulangi Manado \\ Email: imanuelgea@yahoo.com
}

\begin{abstract}
Ovarian cancer is a primary malignancy process of the ovary. This disease is commonly found in woman at post-menopausal age. The causes of ovarian cancer are still unclear. The majority of ovarian cancer are ephitelial cell originated from ovarian ephitelial cells. Another group is non-ephitelial cells that include germinal tumor cell and sex cordstromal tumor cell. This study was aimed to describe types of ovarian cancer at Prof. Dr. R. D. Kandou Hospital Manado. This was a descriptive retrospective study using data of ovarian cancer patients' medical records. There were 95 patients with ovarium cancer in the medical records from January 2013 to December 2015. The majority cases were woman aged $\geq 51$ years, BMI 18.5-24.9, and multipara $(\mathrm{P} \geq 1)$. Conclusion: Ephitelial cell ovarian cancer was the most dominant type followed by germinal cell ovarian cancer.
\end{abstract}

Keywords: ovarian cancer

\begin{abstract}
Abstrak: Kanker ovarium adalah proses keganasan primer yang terjadi pada ovarium. Penyakit ini umumnya dijumpai pada wanita usia pasca menopause dengan penyebab belum jelas. Mayoritas kanker ovarium ialah jenis sel epitelial. Kelompok lainnya ialah non epitelial, termasuk di antaranya sel tumor germinal dan sel tumor sex cord-stromal. Penelitian ini bertujuan untuk mengetahui gambaran jenis kanker ovarium di RSUP Prof. Dr. R.D. Kandou Manado. Jenis penelitian deskriptif retrospektif menggunakan data rekam medik pasien kanker ovarium. Dari hasil penelitian didapatkan 95 orang penderita kanker ovarium periode Januari 2013-Desember 2015 yang memiliki rekam medik. Kejadian terbanyak pada wanita dengan usia $\geq 51$ tahun, IMT 18,5-24,9, multipara $(\mathrm{P} \geq 1)$ dan stadium IIIC. Kanker ovarium epitelial merupakan jenis terbanyak, disusul dengan jenis germinal.
\end{abstract}

Kata kunci: kanker ovarium

Diperkirakan insiden kanker ovarium sekitar 4\% dari seluruh keganasan pada wanita dan menempati peringkat kelima penyebab kematian akibat kanker, dengan angka kematian yang tidak banyak berubah sejak 50 tahun yang lalu. Kanker ovarium umumnya dijumpai pada wanita usia yang lebih tua atau usia pasca menopause. ${ }^{1}$ Kanker ovarium jarang ditemukan pada usia di bawah 40 tahun. Angka kejadian meningkat dengan makin tuanya usia; dari
15-16 per 100.000 pada usia 40-44 tahun, menjadi paling tinggi dengan angka 57 per 100.000 pada usia 70-74 tahun. Usia median saat didiagnosis ialah 63 tahun dan $48 \%$ penderita berusia di atas 65 tahun. $^{2}$

Di Indoneisa, ditemukan kanker ovarium merupakan kanker yang tersering pada wanita (829 kasus baru dan $7,77 \%$ dari semua kanker kanker pada wanita. Tahun 2001 dilaporkan bahwa hasil laporan patologis pada 12 kanker yang terdaftar di 
Indonesia, jumlah kasus kanker ovarium baru ialah 1200 pada tahun $1994 .^{3}$

Penyebab kanker ovarium masih belum jelas, namun beberapa faktor yang mungkin berkaitan dengan timbulnya penyakit ini antara lain: faktor reproduksi, faktor haid, faktor lingkungan dan faktor genetik. $^{4,5}$ Mayoritas kanker ovarium ialah jenis sel epitelial yang berasal dari epitel ovarium. Kelompok lainnya yaitu non epithelial, termasuk di antaranya ialah sel tumor germinal, dan tumor sex-cord stromal. Jenis tumor sex-cord stromal biasanya lebih mudah terdiagnosis dini $( \pm 90 \%$ dapat didiagnosis pada stadium awal) dibandingkan jenis lainnya yang lebih sering terdiagnosis pada stadium lanjut. $^{2}$

Terdapat beberapa stadium pada kanker ovarium yang dibagi menurut International Federation of Gynecology and Obstetri (FIGO) 1988. ${ }^{4}$ Dalam penanganan kanker ovarium dilaksanakan berdasarkan stadium penyakit. Prognosis kanker ovarium buruk pada pasien stadium menengah dan lanjut. ${ }^{5}$

\section{METODE PENELITIAN}

Jenis penelitian ini ialah deskriptif retrospektif, menggunakan data rekam medik penderita kanker ovarium. Penelitian ini dilaksanakan pada bulan September 2016 sampai bulan Oktober 2016 di Bagian Obstetri dan Ginekologi RSUP Prof. Dr. R. D. Kandou Manado. Subjek penelitian ialah seluruh pasien kanker ovarium yang dirawat di RSUP Prof. Dr. R. D. Kandou Manado periode Januari 2013 - Desember 2015. Variabel penelitian ialah usia, indeks massa tubuh (IMT), paritas, stadium klinis penyakit, penanganan, dan jenis sel.

IMT menurut WHO diukur menggunakan rumus $\mathrm{BB}(\mathrm{kg}) / \mathrm{TB}\left(\mathrm{m}^{2}\right)$. Kanker ovarium biasanya terjadi pada wanita usia pasca menopause $\geq 51$ tahun. Penanganan yang diberikan berupa operasi dan kemoterapi. Penentuan stadium kanker ovarium menggunakan protokol FIGO. Terdapat tiga jenis histopatologik yang paling sering pada kanker ovarium.

\section{HASIL PENELITIAN}

Berdasarkan penelitian yang dilakukan di Bagian Obstetri dan Ginekologi RSUP Prof. R.D. Kandou Manado pada periode 1 Januari 2013 - 31 Desember 2015 terdapat 95 wanita yang menderita kanker ovarium.

Tabel 1 menunjukkan karakteristik pasien kanker ovarium berdasarkan usia, IMT, dan paritas. Pasien terbanyak berusia $\geq 51$ tahun yaitu 44 orang $(46,32 \%)$. Menurut IMT didapatkan bahwa pasien kanker ovarium terbanyak pada IMT 18,524,9 yaitu 36 orang $(37,90 \%)$. Selain itu, angka kejadian kanker ovarium ditemukan pada pasien multipara ( $\geq \mathrm{P} 1)$ sebanyak 65 orang $(68,42 \%)$.

Tabel 1. Usia, IMT, dan paritas

\begin{tabular}{lcc} 
& \multicolumn{2}{c}{ Jumlah } \\
\cline { 2 - 3 } & $\mathrm{n}$ & $\%$ \\
\hline Usia & & \\
$\leq 40$ Tahun & 33 & 34,74 \\
41-45 Tahun & 12 & 12,63 \\
46-50 Tahun & 6 & 6,31 \\
$\geq \mathbf{5 1}$ Tahun & $\mathbf{4 4}$ & $\mathbf{4 6 , 3 2}$ \\
\hline Total & 95 & 100 \\
\hline IMT & & \\
$\leq 18,5$ & 9 & 9,47 \\
$\mathbf{1 8 , 5 - 2 4 , 9}$ & $\mathbf{3 6}$ & $\mathbf{3 7 , 9 0}$ \\
$25-29,9$ & 12 & 12,63 \\
$\geq 30$ & 1 & 1,05 \\
Tidak ada data & 37 & 38,95 \\
\hline Total & 95 & 100 \\
\hline Paritas & & \\
$\mathbf{P}_{0}$ & 23 & 24,21 \\
$\mathbf{P}_{1}$ & 7 & 7,37 \\
$\geq \mathbf{P}_{\mathbf{1}}$ & $\mathbf{6 5}$ & $\mathbf{6 8 , 4 2}$ \\
\hline Total & 95 & 100 \\
\hline
\end{tabular}

Tabel 2 menunjukkan stadium klinis penyakit kanker ovarium. Terdapat 3 orang $(3,16 \%)$ stadium IC, 10 orang $(10,53 \%)$ stadium IIIC dan 5 orang $(5,26 \%)$ stadium IV. Selain itu, pada data rekam medik terdapat 1 orang $(1,05 \%)$ dengan stadium awal dan 4 orang $(4,21 \%)$ dengan stadium lanjut. terdapat sebanyak 72 orang $(75,79 \%)$ yang tidak memiliki data. Hal ini dikarenakan data medik yang diteliti kurang lengkap dan rinci dalam menuliskan stadium klinis penyakit. 
Tabel 2. Stadium klinis penyakit kanker ovarium

\begin{tabular}{lcc}
\cline { 2 - 3 } & \multicolumn{2}{c}{ Jumlah } \\
\cline { 2 - 3 } & $\mathrm{n}$ & $\%$ \\
\hline Stadium & 0 & 0 \\
IA & 0 & 0 \\
IB & 3 & 3,16 \\
IC & 0 & 0 \\
IIA & 0 & 0 \\
IIB & 0 & 0 \\
IIC & 0 & 0 \\
IIIA & 0 & 0 \\
IIIB & $\mathbf{1 0}$ & $\mathbf{1 0 , 5 3}$ \\
IIIC & 5 & 5,26 \\
IV & 1 & 1,05 \\
Stadium Awal & 4 & 4,21 \\
Stadium Lanjut & 72 & 75,79 \\
Tidak ada data & 95 & 100 \\
Total & &
\end{tabular}

Tabel 3 menunjukkan penanganan yang didapatkan pasien kanker ovarium selama dirawat di RSUP Prof. DR. R.D. Kandou Manado. Terdapat 68 orang $(71,56 \%)$ yang dilakukan operasi, 59 orang $(62,10 \%)$ dilakukan kemoterapi, dan 34 orang $(35,79 \%)$ dilakukan operasi diikuti dengan kemoterapi. Terdapat 2 orang $(2,10 \%)$ tanpa data medik.

Tabel 3. Penanganan pasien kanker ovarium

\begin{tabular}{lcc}
\cline { 2 - 3 } & \multicolumn{2}{c}{ Jumlah } \\
\cline { 2 - 3 } & $\mathrm{n}$ & $\%$ \\
\hline Penanganan & $\mathbf{6 8}$ & $\mathbf{7 1 , 5 6}$ \\
Operasi & 59 & 62,10 \\
Kemoterapi & 34 & 35,79 \\
Operasi + Kemoterapi & 2 & 2,10 \\
Tidak ada data & & \\
\hline
\end{tabular}

Tabel 4 menggambarkan jenis sel dari kanker ovarium. Ditemukan 38 pasien $(40,00 \%)$ dengan jenis sel tumor epitelial, terdiri dari 24 pasien dengan jenis musinosum, 7 pasien dengan jenis serosum, 4 pasien dengan jenis endometrioid, dan 2 pasien dengan jenis tidak terdiferensiasi. Terdapat 7 pasien $(7,37 \%)$ dengan jenis sel germinal, terdiri dari 4 pasien dengan jenis disgerminoma dan 2 pasien dengan jenis teratoma. Terdapat 50 pasien $(52,63 \%)$ tanpa catatan medik mengenai jenis sel kanker ovarium.

Tabel 4. Jenis sel kanker ovarium

\begin{tabular}{lcc}
\cline { 2 - 3 } & \multicolumn{2}{c}{ Jumlah } \\
\cline { 2 - 3 } & $\mathrm{n}$ & $\%$ \\
\hline Jenis sel & & \\
Sel tumor epitelial & $\mathbf{3 8}$ & $\mathbf{4 0 , 0 0}$ \\
Sel tumor germinal & 7 & 7,37 \\
Sel tumor stromal & 0 & 0 \\
Tidak ada data & 50 & 52,63 \\
\hline Total & 95 & 100 \\
\hline
\end{tabular}

\section{BAHASAN}

Hasil penelitian yang telah dilakukan menggunakan data rekam medik dari 95 pasien kanker ovarium di RSUP Prof. Dr. R. D. Kandou Manado. Karakteristik pasien kanker ovarium berdasarkan umur, IMT dan paritas didapatkan bahwa pasien terbanyak yaitu usia $\geq 51$ tahun yaitu berjumlah 44 orang $(46,32 \%)$. Usia tersebut merupakan usia post menopause, dimana hal ini menjadi salah satu faktor risiko yang berperan dalam terjadinya kanker ovarium, walaupun pengaruhnya tidak terlalu besar. ${ }^{5}$ Dilihat dari IMT, sebanyak 36 orang $(37,90 \%)$ pasien kanker ovarium memiliki IMT 18,5-24,9. IMT pada pasien ovarium umumnya rendah, sebab biasanya pasien ovarium mengalami penurunan berat badan sebagai manifestasi klinis. ${ }^{6}$ Selain itu, ditemukan pula 23 orang $(24,21 \%)$ dengan nulipara $\left(\mathrm{P}_{0}\right), 7$ orang $(7,37 \%)$ dengan primipara $\left(\mathrm{P}_{1}\right)$ dan 65 orang $(68,42 \%)$ dengan multipara $\left(\geq \mathrm{P}_{1}\right)$. Hal ini tidak sesuai dengan teori dan berbagai penelitian yang menunjukan bahwa wanita dengan paritas yang tinggi memiliki risiko terjadinya kanker ovarium yang lebih rendah daripada nulipara. ${ }^{2}$ Terdapat banyak faktor yang bisa menjadi penyebabnya, antara lain pada wanita dengan paritas rendah memiliki siklus ovulasi yang tinggi sehingga meningkatkan resiko timbulnya kanker ovarium. $^{4}$

Kanker Ovarium adalah proses keganasan primer yang terjadi pada organ ovarium dan juga merupakan penyebab kematian tertinggi dari kanker alat genital 
perempuan. $^{4,6}$ Kanker ovarium pada umumnya dijumpai pada wanita usia yang lebih tua atau usia post menopause. ${ }^{1}$ Kanker ovarium jarang ditemukan pada usia di bawah 40 tahun. Angka kejadian meningkat dengan makin tuanya usia. Usia median saat didiagnosis adalah 63 tahun dan $48 \%$ penderita berusia di atas 65 tahun. ${ }^{2}$ Selain usia dan juga paritas yang menjadi faktor risiko yang berperan dalam terjadinya kanker ovarium, faktor herediter juga perlu mendapat perhatian khusus dimana sekitar 20\%-25\% wanita yang didiagnosis dengan kanker ovarium memiliki kecenderungan riwayat keluarga yang memiliki penyakit serupa. ${ }^{7}$

Dijumpai 225.000 kasus baru kanker ovarium seluruh dunia pada tahun 2008 . Angka insidensi sangat bervariasi di dunia, di mana negara-negara maju hampir dua kali lebih tinggi di bandingkan negaranegara kurang berkembang. Angka kejadian untuk daerah yang lebih berkembang adalah 9 per 100.000 dan 5 per 100.000 untuk negara kurang berkembang. Insiden tertinggi dicatat di Eropa Utara, Tengah dan Timur, diikuti oleh Eropa Barat dan Amerika Utara, dan tingkat terendah di Afrika dan sebagian Asia (negara Jepang paling rendah). ${ }^{1}$

Data stadium klinis penyakit menunjukkan sebagian besar pasien kanker ovarium yang memiliki data medik berada pada stadium IIIC (10 orang) dan IV (5 orang). Namun, karena kurang lengkapnya data, sebanyak 72 orang tidak memiliki data medik stadium klinis penyakit.

Sebagian besar pasien kanker pasien kanker ovarium terdiagnosis penyakit ini pada stadium lanjut. Oleh karena itu penyakit ini dikenal sebagai "silent killer". Hal ini diakibatkan oleh gejala penyakit yang asimtomatik (95\%) dan keluhankeluhan yang timbul tidak spesifik seperti perut kembung, nyeri perut, dispareunia, berat badan meningkat karena ada asites atau massa. Keluhan tersering dari pasien adalah perut kembung tidak nyaman, mudah dikelirukan sebagai dispepsia. ${ }^{4,5}$ Dalam hal ini perlu pengetahuan dari pasien tentang deteksi dini. Karena pada pasien yang terdiagnosis dini (stadium I), 90\% dari pasien dapat disembuhkan dengan operasi konvensional dan kemoterapi. Sedangkan pada stadium lanjut, kurang dari $30 \%$ pasien dapat bertahan jangka panjang. ${ }^{8}$

Data penanganan yang diberikan pada pasien kanker ovarium terdapat 68 orang $(71,56 \%)$ dilakukan operasi, 59 orang $(62,10 \%)$ dilakukan kemoterapi dan 34 orang $(35,79 \%)$ dilakukan operasi diikuti dengan kemoterapi.

Penanganan kanker ovarium sangat ditentukan oleh stadium, derajat diferensiasi, fertilitas pada usia reproduksi dan keadaan umum pasien. Pengobatan utama adalah operasi pengangkatan tumor primer dan metastasisnya, dan bila perlu diberikan kemoterapi. ${ }^{2}$

Dari hasil pemeriksaan histopatologik ditemukan 38 orang $(40,00 \%)$ dengan jenis sel tumor epitelial yang berasal dari sel epitel yang membungkus fimbria tuba fallopi, atau ovarium. ${ }^{9}$ Sel ini merupan jenis sel yang paling banyak ditemukan pada pasien kanker ovarium. Lebih dari 80\% kanker ovarium epitelial ditemukan pada wanita usia post menopause. Kanker ovarium epitelial ini jarang ditemukan pada usia kurang dari 45 tahun. Pada usia kurang dari 21 tahun kanker epitelial ini sangat jarang ditemukan. Pada wanita pra menopause hanya $7 \%$ tumor ovarium epitelial yang ganas. ${ }^{2}$ Hasil penelitian dari pasien dengan jenis sel epitelial, terdapat 24 orang dengan jenis musinosum, 7 orang dengan jenis serosum, 4 orang dengan jenis endometrioid dan 2 orang dengan jenis tidak terdiferensiasi. Selain itu, ditemukan pula 7 orang $(7,37 \%)$ dengan jenis sel germinal yang berasal dari sel germinal primordial ovarium. Sel ini biasanya ditemukan pada wanita usia lebih muda. ${ }^{10}$ Kira-kira 20-25\% tumor ovarium berasal dari sel germinal, tetapi hanya $3 \%$ yang ganas. $^{2}$ Dari hasil penelitian dari pasien dengan jenis sel germinal, terdapat 4 orang dengan jenis disgerminoma dan 2 orang dengan jenis teratoma. 


\section{SIMPULAN}

Dari hasil penelitian, didapatkan pasien kanker ovarium terbanyak pada usia $\geq 51$ tahun. Angka kejadian terbanyak wanita dengan IMT 18,5-24,9 dan multipara. Stadium IIIC merupakan stadium terbanyak yang ditemukan dalam penelitian ini. Operasi merupakan penanganan terbanyak, disusul dengan kemoterapi. Jenis kanker yang paling banyak ditemukan adalah jenis sel tumor epitelial.

\section{SARAN}

Diharapkan upaya promotif dan preventif terhadap kanker ovarium bisa lebih ditingkatkan agar dapat menurunkan angka morbiditas dan mortalitas serta meningkatkan angka harapan hidup penderita kanker ovarium.

Sebaiknya catatan rekam medik berupa IMT, stadium klinis penyakit dan jenis sel diperbaiki dan dilengkapi sehingga dapat bermanfaat bagi penelitian selanjutnya.

Diharapkan pada penelitian selanjutnya dapat mencantumkan faktor keluarga dan pencegahan yang dilakukan terhadap kanker ovarium.

\section{DAFTAR PUSTAKA}

1. Waruwu D. Hubungan usia penderita dengan gambaran histopatologi kanker ovarium di kota medan tahun 2010-2011 [Tesis]. Medan: Fakultas Kedokteran Universitas Sumatera Utara; 2013.

2. Busmar B. Kanker ovarium. In: Aziz MF, Andrijono, Saifuddin AB, editors. Onkologi ginekologi (1st ed). Jakarta:
Bina Pustaka Sarwono Prawirohardjo, 2010; p. 468-27.

3. Putri H, Suriyantara B, Putra K, Trirahmanto A, Kusumanto A. Risk of malignancy index of ovarian cancer patients in Dr. Sardjito Hospital, Yogyakarta. Yogyakarta: Fakultas Kedokteran Universitas Gadjah Mada; 2010.

4. Kampono N. Tumor ganas alat genitalKanker ovarium. In: Anwar M, Baziad A, Prabowo R, editors. Ilmu Kandungan (3rd ed). Jakarta: Bina Pustaka Sarwono Prawirohardjo, 2011; p. 307-11.

5. Jihong L. Tumor ganas ovarium. In: Desen W, editor. Buku Ajar Onkologi Klinis (2nd ed). Jakarta: Balai Penerbit FKUI, 2011.

6. Himpunan Onkologi Ginekologi Indonesia. Kanker ovarium. Kanker Ginekologi. (3rd ed). Jakarta, 2013; p. 89-01.

7. Ovarian Cancer Research Fund Alliance (OCRFA). Risk Factors. Ovarian Cancer. 2016 [cited 7 Nov 2016]. Available from: https: //ocrfa.org/patients/about-ovariancancer/risk-factors/

8. Badgwell, Donna, Bast J, Robert C. Biomarkers in ovarian disease. USA: Department of Experimental Therapeutics, University of Texas; 2007.

9. Green A. Ovarian Cancer. 24 Agustus 2016 [cited 6 Sep 2016]. Avilable from: http://emedicine.medscape.com/articl e/255771-overview\#a3

10 Callahan T, Caughey A. Obstetrics \& Gynecology (6th ed). LWW, 2013; p. 392-95 